\title{
Improvement of Eggless Cake Structure Using Ultrasonically Treated Whey Protein
}

\author{
M. C. Tan • N. L. Chin • Y. A. Yusof • F. S. Taip • \\ J. Abdullah
}

Received: 15 June 2014 / Accepted: 17 October 2014 / Published online: 5 November 2014

(C) The Author(s) 2014. This article is published with open access at Springerlink.com

\begin{abstract}
Ultrasound treatment was applied on whey protein concentrate suspension prior to foaming and being mixed into batter for eggless cake baking. The improvement of batter and baked cake made using ultrasound treated whey protein were measured in terms of aeration, rheological and textural properties. Baked cakes formulated with untreated whey protein suspension at varying concentrations between 10 and $20 \%$ were compared with ultrasound treated whey protein up to $25 \mathrm{~min}$ at $60 \%$ amplitude. Visualized images of aerated cake products using $\mathrm{x}$-ray tomography technique supported the findings of improved batter in terms of density decrease by $5 \%$, and viscosity, consistency index, storage modulus, and loss modulus increase by $31,57,33$, and $21 \%$, respectively. For baked cakes, volume increase was $18 \%$, and density, hardness, and chewiness decrease was 18,65 , and $64 \%$, respectively, when compared to those made using untreated whey protein. Image analysis presented a higher number of smaller gas cells in the aerated baked cakes structure using ultrasound treated whey protein.
\end{abstract}

Keywords Ultrasound . Whey protein $\cdot$ Egg white protein . Batter $\cdot$ Eggless cake $\cdot \mathrm{X}$-ray tomography

\footnotetext{
M. C. Tan $\cdot$ N. L. Chin $(\triangle) \cdot$ Y. A. Yusof $\cdot$ F. S. Taip

Department of Process and Food Engineering, Faculty of Engineering, Universiti Putra Malaysia, 43400 Serdang, Selangor, Malaysia

e-mail: chinnl@upm.edu.my

J. Abdullah

Plant Assessment Technology Group, Malaysian Nuclear Agency

(Nuclear Malaysia), Bangi, 43000 Kajang, Selangor, Malaysia
}

\section{Introduction}

Egg protein is essential and normally used in many food formulations as a foaming ingredient in bakery food products to give great contribution on structure of batter and baked cake for its appearance and textural appeal. Today, people tend to reduce egg intake for several reasons including egg cholester$\mathrm{ol}$ and specific dietary needs of the vegans, vegetarians, and egg allergy consumers (Ashwini et al. 2009). With consumers actively searching for healthier food options with no sacrifice for its taste and appearance, food manufacturers constantly look for alternatives of egg in food manufacture. The trials of substitutes of eggs in cake products, such as total replacement with white lupine protein, emulsifiers, and xanthan gum in yellow cakes (Arozarena et al. 2001), and bovine plasma protein in high yield white cakes (Lee et al. 1993; Myhara and Kruger 1998; Raeker and Johnson 1995), were not successful in replacing egg's attribute and contribution in foaming. The egg white protein is critical for foaming in the angel food cake (Abu-Ghoush et al. 2010; McWilliams 2008).

Whey protein, which has high nutritional values and contains all essential amino acids that are higher in concentration compared to vegetable proteins such as soy, corn, and wheat gluten (Recio et al. 2008), comes into solution for partial or total egg white protein replacement in cake baking. Unfortunately, the baked cake product quality was not comparable with fully egg white formulated cakes. In the study of total whey protein replacement in angel food cakes, cakes containing whey protein were smaller in volume due to the lower stability of cake batter to help in prevention of cake collapse (Pernell et al. 2002). Partial replacement of egg white protein with whey protein isolate in angel food cake also showed an overall poorer quality, with lower cake volume and coarser bubbles structure, which was probably due to the higher denaturation temperature of whey protein that resulted in 
higher coagulation temperature and caused over-expanded gas cells in cake batter to collapse during baking (Arunepanlop et al. 1996). Berry et al. (2009) also found that the angel food cake network containing whey protein isolate was not stable and had larger gas cells.

To obtain a pleasurable mouthfeel and appearance of cake using whey protein, sucrose was incorporated in the making of angel food cake to improve its functional properties. Berry et al. (2009) reported that sucrose gave little positive effect on whey protein isolate usage where batter with low stability prior to and during heating was obtained. Yang and Foegeding (2010) showed that the incorporation of sucrose has altered the volume of angel food cakes prepared from whey protein foams with large gas cells, giving a coarse structure which collapsed due to bubbles collapse and rupture of films surrounding bubbles. It indicated the poor stability of whey proteins in the conversion from a wet to a dry foam in angel food cake (Yang and Foegeding 2010). Besides sucrose addition to enhance the functional properties of whey protein, Nakai and Li-Chan (1985) also found that the whipping properties of whey protein can be improved by pepsin hydrolysis addition to increase protein solubility, while gelling properties of whey protein can be enhanced by polyphosphate addition to increase its exposable hydrophobicity despite unsatisfactory final results of angel food cake. Besides material aided substitution, some techniques have been applied to enhance the functional properties of whey protein in egg white protein replaced cakes, such as heat treating on whey proteins in angel food cake making (Pernell et al. 2002) and application of air pressure up to 1.5 bar in the oven during baking (Morr et al. 2003). The results show that none of the cakes exhibited satisfactory properties even when the volume was increased, but still not to the extent of egg white proteins. Recent studies using ultrasound in baking process included Harris (2011), who produced gluten-free products with improved texture, and Tan et al. (2011), who reported improved cake aeration with lower hardness and density. Other works that have applied ultrasound on proteins, which have measured changes in protein solubility, conductivity, foam ability (Jambrak et al. 2008), size of fat globule, protein denaturation (Villamiel and de Jong 2000), consistency index, and gelation properties (Arzeni et al. 2012), suggested that proteins induced by ultrasound have potential in structural and functional improvements (Gülseren et al. 2007).

The objective of this study was to use ultrasound treated whey protein concentrate as a total replacement of egg white protein in angel food cake making. The quality of batter and cake formulated with ultrasound treated whey protein concentrate were compared with untreated whey protein and also with egg white protein.

\section{Materials and Methods}

\section{Materials}

The ingredients used in the formulation of angel food cake were commercial low protein flour with 7-9.5\% protein (Brand Gold Key; FFM Berhad, Selangor, Malaysia), whey protein concentrate (Textrion PROGEL 800; DMV International, BA Veghel, Netherlands), egg white powder (Pulviver SPRL, Belgium), caster sugar (Tien Swee Trading Sendirian Berhad, Kuala Lumpur, Malaysia), and salt (Seng Hin Brothers Enterprises Sendirian Berhad, Selangor, Malaysia).

\section{Protein Suspension Preparation and Ultrasound Treatment}

The aqueous suspensions of powdered whey protein concentrate or egg white powder were prepared by dispersing 10,15 , and $20 \%(\mathrm{w} / \mathrm{w})$ of dry matter into $250 \mathrm{~g}$ with distilled water in a 500-ml beaker and stirred using a mechanical stirrer [RW20 DZM.n S2; IKA Works (Asia) Sendirian Berhad, Malaysia] at $355 \mathrm{rpm}$ for 20 min until homogenous suspensions were obtained. The whey protein suspensions were sonicated using a high-intensity ultrasound probe $(20 \mathrm{kHz}-400 \mathrm{~W}$ Digital Sonifier Model 450; Branson Ultrasonics Corporation, Danbury, Connecticut, USA) at 20, 40, or $60 \%$ amplitude for 5 , 15 , or $25 \mathrm{~min}$. The maximum setting of amplitude and sonication time was based on pre-run where whey protein suspension could sustain without transforming into gel. The probe with a vibrating titanium tip of $2.54 \mathrm{~cm}$ was immersed in half level at the center of the liquid medium. The control samples were those without ultrasonic treatment while egg white protein was used for the purpose of comparison with the conventional cake making recipe using eggs.

\section{Production of Cake}

The formulation of angel food cake was adapted from the work of Yamazaki and Lord (1971) as in Table 1. It was chosen in this study because of its simplicity as a common type of sponge cake, which is known for its airy lightness texture (Anonymous 2013). The ingredients were weighed on scales using an analytical balance (SB12001; Mettler Toledo,

Table 1 Angel food cake formulations

\begin{tabular}{lll}
\hline Ingredients & Flour base (\%) & Mass of cake loading (g) \\
\hline Flour & 100 & 100 \\
Sugar & 250 & 250 \\
Salt & 3 & 3 \\
Protein suspension & 250 & 250 \\
Total mass & & 603 \\
\hline
\end{tabular}


Switzerland). Treated protein suspension was loaded directly into a mixer (5K5SSS; Kitchen Aid Inc., St. Joseph, Michigan, USA) and whipped for $15 \mathrm{~min}$ at $330 \mathrm{rpm}$ until it was fully foamed. Sugar was then added into the foam during the extended mixing of $4 \mathrm{~min}$. Mixing continued for another $4 \mathrm{~min}$ at a reduced speed of $160 \mathrm{rpm}$ where pre-mixed salt with sifted flour was added to obtain cake batter. The mixing of cake batter at the final $15 \mathrm{~s}$ was increased back to $330 \mathrm{rpm}$. Then $450 \mathrm{~g}$ of cake batter was poured into a cake tin with a diameter of $20 \mathrm{~cm}$ at top, $19 \mathrm{~cm}$ at center, and $18 \mathrm{~cm}$ at bottom, and baked at $170{ }^{\circ} \mathrm{C}$ with oven heat levels setting of $20 \%$ (top): $30 \%$ (side): $10 \%$ (bottom) for $40 \mathrm{~min}$ in an electronic baking oven (ST-02; Salva Industrial, Spain). Baked cake was inverted on a wire rack immediately and cooled for $5 \mathrm{~min}$ before removing it from the tin. The cake was left in the ambient for further cooling for $1 \mathrm{~h}$ (Gómez et al. 2008; Tan et al. 2011) before cake analysis.

Batter Density and Rheology

Batter density was obtained from the weight-volume ratio of batter filled and leveled in a standard-volume $114-\mathrm{cm}^{3}$ cup (Eq. 1) (Allais et al. 2006a, b; Tan et al. 2010, 2011). The average of five samples was taken from the same batch of cake batter mix with a repeated run.

Density $_{\text {batter }}=\frac{\text { Mass }_{\text {batter }}}{\text { Volume }_{\text {cup }}}$

The rheological properties of fresh batter from each batch of mix was measured using a rheometer (AR-G2; TA Instruments, New Castle, USA) with a 40-mm-diameter serrated plate-plate geometry set at a constant gap height of $2.4 \mathrm{~mm}$ at $25^{\circ} \mathrm{C}$ (Mleko et al. 2007). The storage modulus $G^{\prime}$ and loss modulus $G^{\prime \prime}$ of the batter were measured through a frequency sweep test within the linear viscoelastic region from 0.1 to $10 \mathrm{~Hz}$ at strain value of $1.00 \times 10^{-3}$. Loss tangent values, $\tan \delta$, were then calculated from those $G^{\prime}$ and $G^{\prime \prime}$ values using Eq. 2 (Ikeda and Nishinari 2001).

$\tan \delta=\frac{G^{\prime \prime}}{G^{\prime}}$

The data of shear stress $\tau(\mathrm{Pa})$ versus shear rate $\gamma(1 / \mathrm{s})$ was generated by linearly increasing the shear rates from 0 to $100 \mathrm{~s}^{-1}$ in $5 \mathrm{~min}$ and then fitted into Power law model as in Eq. 3 to evaluate its flow behavior (Sakiyan et al. 2004; Salvador et al. 2003; Turabi et al. 2008) in terms of consistency index $K\left(\mathrm{~Pa} \cdot \mathrm{s}^{n}\right)$ and the flow behavior index $n$.

$\tau=K \gamma^{n}$

$K$ and $n$ in Power law were determined by curve fitting using the solver function in Microsoft Excel adopting the generalized reduced gradient (GRG2) nonlinear optimization code (Tan et al. 2011). The goodness of fit, $R^{2}$, was calculated as $R^{2}=1-\frac{\mathrm{SSE}}{\mathrm{SST}}$, where $\mathrm{SSE}$ is the sum of square errors and SST is the total corrected sum of squares (Chin et al. 2009). The determination of viscosity was chosen at shear rate of $5.5 \mathrm{~s}^{-1}$ from the Power law fitting in terms of apparent viscosity, $\eta$ (Eq. 4), to reflect batter viscosity properties at mixing speed of $330 \mathrm{rpm}$.

$\eta=K \gamma^{n-1}$

Similarly, the results of $G^{\prime}$ and $G^{\prime \prime}$ were reported at $5.5 \mathrm{~Hz}$ which corresponded with $5.5 \mathrm{~s}^{-1}$ as to match batter mixing rate of $330 \mathrm{rpm}$. An equivalent time sweep test was conducted to ensure batter sample surfaces were not drying up within the experimental time of $10 \mathrm{~min}$. In addition, fresh samples were loaded for every sample used and the experiment was repeated once.

\section{Cake Volume and Density}

Volume of cake was measured using coriander seeds displacement method (Lebesi and Tzia 2012; Sahin and Sumnu 2006; Tan et al. 2010, 2011). A $6,220-\mathrm{cm}^{3}$ container was first filled with $1,000 \mathrm{~cm}^{3}$ of coriander seeds before the cake was placed on it and overfills with remaining space in the container with more seeds and tap before the surface was leveled with a ruler. The total volume of seeds used was calculated by dividing the mass of seeds to the pre-determined density of seeds, $731.46 \mathrm{~kg} / \mathrm{m}^{3}$, following Eq. 5. The volume of cake was obtained as the difference between the volume of the container and the volume of seeds that occupied the container following Eq. 6. Cake density is equal to the mass of cake divided by its volume as in Eq. 7. Sample of cake volume and density was in unity and the experiment was repeated once.

Volume $_{\text {seeds }}=\frac{\text { Mass }_{\text {seeds }}}{\text { Density }_{\text {seeds }}}$

Volume $_{\text {cake }}=$ Volume $_{\text {container }}-$ Volume $_{\text {seeds }}$

Density $_{\text {cake }}=\frac{\text { Mass }_{\text {cake }}}{\text { Volume }_{\text {cake }}}$

Texture Profile Analysis of Cake

The texture profile analysis (TPA) of cake was performed using a texture analyzer (TA-XT ${ }_{\text {plus }}$; Stable Micro Systems, Surrey, UK). The cake sample was compressed twice with a 2.54-cm-diameter cylinder probe to a fixed distance of $10 \mathrm{~mm}$ 
depth in the TPA test. The auto trigger feature was set at $5 \mathrm{~g}$ where upon sensing, it will withdraw from the cake to its original height after the first compression. Before a second compression was repeated to precisely determine the original penetration distance, the cake sample was allowed to recover for $3 \mathrm{~s}$. The pre-test speed, test speed, and post-test speed were all set to $2.0 \mathrm{~mm} / \mathrm{s}$ in the TPA test. Cake hardness, chewiness, cohesiveness, and resilience are the textural properties measured and obtained through textural profile analysis. The data was collected at $200 \mathrm{pps}$. A cake from each batch was cut into quarters from the center layer of the cake with dimension of $5.08 \times 5.08 \times 2.54 \mathrm{~cm}$, providing four trials of sample per batch of baked cakes with the entire experiment repeated once (Tan et al. 2010, 2011).

\section{Imaging of Aerated Cake Structure}

Bubble size distribution of the aerated cake structure was imaged using 2D x-ray tomography. The whole cake sample was placed on an adjustable rotational stage which was $54 \mathrm{~cm}$ from the x-ray source and $58 \mathrm{~cm}$ from the detector, all arranged in a line. The $\mathrm{x}$-ray tube was set at $100 \mathrm{kV}$ and $2 \mathrm{~mA}$. The camera pixel size was $230 \times 1310$ with no filter. Each cake was scanned at the center and the cake images were taken every $0.5^{\circ}$ around a $360^{\circ}$ path. The scanned images were constructed using Backprojection software to obtain 2D images for bubbles size analysis. It was then analyzed using Adobe Photoshop CS2 with Fovea Pro 4.0 plug-in software. The number of bubbles at size ranges 0 to $10 \mathrm{~mm}^{2}$ was analyzed at each quarter at $200 \times 200$ pixels.

\section{Experimental Design and Statistical Analysis}

Three sets of experiments were designed by varying either the whey protein concentration of 10,15 , and $20 \%$, ultrasonic treatment amplitudes of 20,40 , and $60 \%$, or treatment duration of 5, 15, and $25 \mathrm{~min}$ such that the other two factors were held at its highest level in each set of experiment. Batter density samples were in triplicates; batter rheology, cake volume, and density samples were unity; and textural properties of cake were measured from four pieces cut from a cake with the entire experiment repeated once. The error bars in the graphs are the standard deviation of means. Unstacked oneway analysis variance was performed using the statistical analysis in Minitab software (version 16; Minitab Statistical Software, USA).

\section{Results and Discussion}

\section{Batter Density and Viscosity}

Figure 1a shows the two most important cake batter parameters, its density and viscosity, for they have direct impact on overall cake quality in terms of volume and appearance. Gómez et al. (2010) mentioned that batter viscosity was measured to ensure the production of cake with good volumes. This is because viscosity in cake batter is known for its function of retaining trapped air, which in turn gives the raised volume of baked cake. In general, whey protein seems to give lower batter viscosity than the egg. Despite the lower viscosities, whey proteins at higher concentration of 15 to $20 \%$ had the capability of retaining trapped air from the low batter density displayed. Cake batter formulated with whey has a wider range in density while cake batter formulated with egg has a wider range of viscosity suggesting differing nature and characteristics for its effectiveness of manipulations of batter density and viscosity, respectively. The similarities found between the two proteins are that batter density decreased and viscosity increased with protein concentration. This is in agreement with Damodaran (1997) who reported that viscosity of protein solutions generally increased exponentially with protein concentration due to increased interaction between the hydrated protein molecules.
Fig. 1 Batter density $(\square \cdot \square)$ and batter viscosity (- $)$ of a untreated egg and whey protein, and $\mathbf{b}$ ultrasound treated whey protein

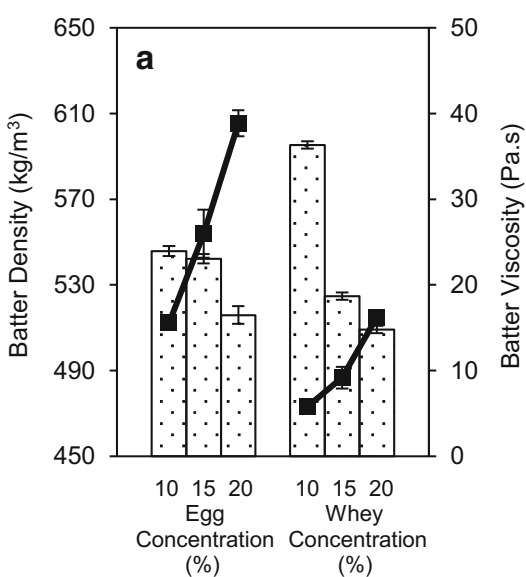

(\%)

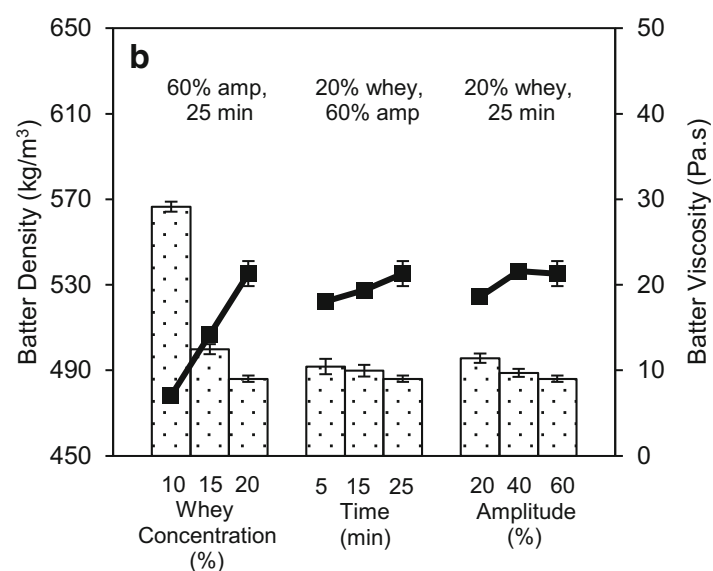

(\%) 
Figure $1 \mathrm{~b}$ shows that ultrasound application on whey protein suspension has increased batter viscosity and produced lower batter density. Both ultrasound amplitude and time increased batter viscosity significantly at $p<0.05$ and $p<0.1$, respectively. Both factors also gave more prominent effects to batter density with significant difference at $p<0.001$. Ultrasound treated whey protein at highest amplitude of $60 \%$ and for the longest studied duration of $25 \mathrm{~min}$ gave relatively higher batter viscosity and lower density compared to the untreated whey protein at its respective concentrations (Fig. 1a). The resulted higher batter viscosity was due to the higher foam viscosity (Tan et al. 2014) caused by protein denaturation induced by sonication effect in protein suspension. The partial denaturation of protein causes an increase in the hydrodynamic size of proteins and results in higher viscosity (Damodaran 1997). The foam and batter with high viscosity in turn provides a stable film for gas bubbles to hold trapped air in the cake batter system, hence results in a lower batter density.

\section{Consistency and Flow Behavior Index of Batter}

Figure 2 shows the rheological property of consistency index, $K$, which is commonly measured in cake batter for evaluation of its capacity to retain the air (Gómez et al. 2010; Sakiyan et al. 2004; Tan et al. 2011), and flow behavior index, $n$, as an indication of its fluid flow. Protein concentration from both egg and whey protein formulated batters increased the consistency index generally with greater increase for the egg formulated (Fig. 2a). Both egg and whey protein formulated batters exhibited shear thinning or pseudoplastic behavior with $n$ values below 1 ( elik et al. 2007). The pseudoplastic behavior is the consequence of the tendency of protein molecules to orient their major axis in the direction of flow (Damodaran 1997) and has increased with protein concentration. It was also higher for the egg formulated batter compared to whey. Batters with more pseudoplasticity were also higher in consistency index and had higher capacity to retain air (Fig. 1a).
Figure $2 \mathrm{~b}$ shows that consistency index increased significantly with ultrasound amplitude and sonication time with $p$ $<0.05$, while flow behavior index decreased with ultrasound amplitude more significantly $(p<0.01)$ than sonication time $(p<0.1)$. Ultrasound treated whey protein at maximum amplitude of $60 \%$ and duration of $25 \mathrm{~min}$ have increased $K$ values of batter by 10,63 , and $57 \%$ compared to the untreated whey protein for respective concentration of 10,15 , and $20 \%$. The $n$ values of batter decrease were observed at 15 and $20 \%$ concentration. Ultrasound treatment altered protein conformation and structure by exposing the hydrophilic parts of amino acids which are buried in the protein interior towards water surroundings leading to higher binding in water molecules (Krešić et al. 2008). The increased binding capacity of protein with water contributes to the changes in flow behavior, consistency index, and apparent viscosity (Krešić et al. 2008). Boye et al. (1997) mentioned that hydrogen bonding in the protein suspension precedes the onset of coagulation and serve as the most important cross-linking for increased viscosity (Fig. 1).

\section{Viscoelastic Properties of Batter}

Figure 3a shows that viscoelastic properties of whey protein formulated batter had much lower and narrower range compared to those from egg. This shows that viscoelasticity of batter was dependent on protein type. Proteins with $\tan \delta$ value $>0.1$ can give rise to weak gel (Fig. 4a) (Ikeda and Nishinari 2001). Whey protein at $10 \%$ concentration had $\tan \delta$ value of 1 indicating that the batter was low in viscoelasticity (Matos et al. 2014). Cake batter formulated at low whey protein concentration of $10 \%$ was more viscous in nature with lower ratios of $G^{\prime} / G^{\prime \prime}$ and it gets more elastic or solid like towards higher protein concentration of 15 to $20 \%$ with increased $G^{\prime}$ value. Although $G^{\prime}$ and $G^{\prime \prime}$ of both proteins increased with concentrations, $\tan \delta$ decrease suggested that the solid-like property of batter increases (Matos et al. 2014). The fact that $G^{\prime}$ and $G^{\prime \prime}$ increase could be simply due to the effect of the
Fig. 2 Consistency index (ב) and flow behavior index (-1) of a untreated egg and whey protein, and $\mathbf{b}$ ultrasound treated whey protein

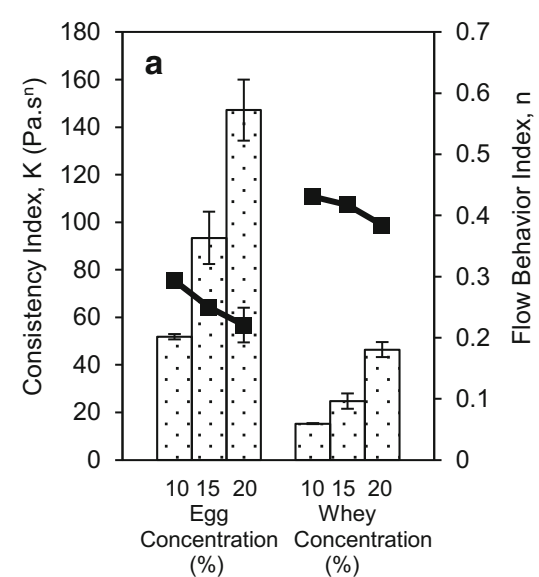

(\%)
(\%)

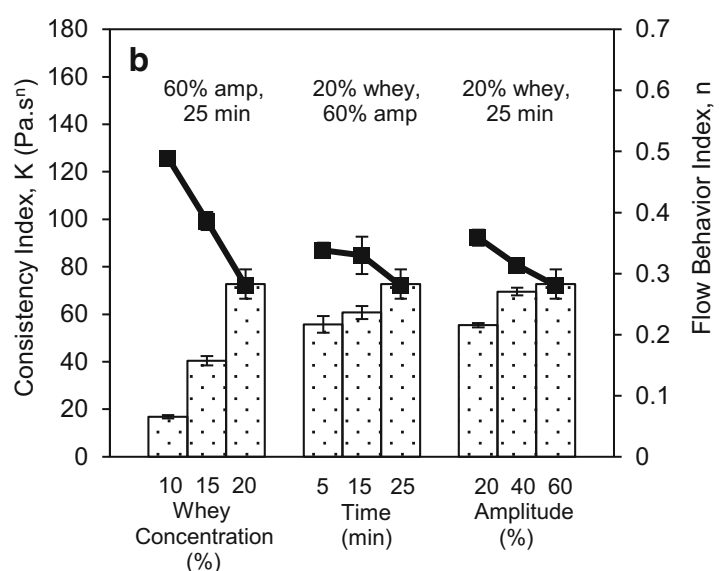

(\%) 
Fig. 3 Storage modulus ( $\square$ (ב) and loss modulus $(-\mathbf{C})$ of a untreated egg and whey protein, and $\mathbf{b}$ ultrasound treated whey protein
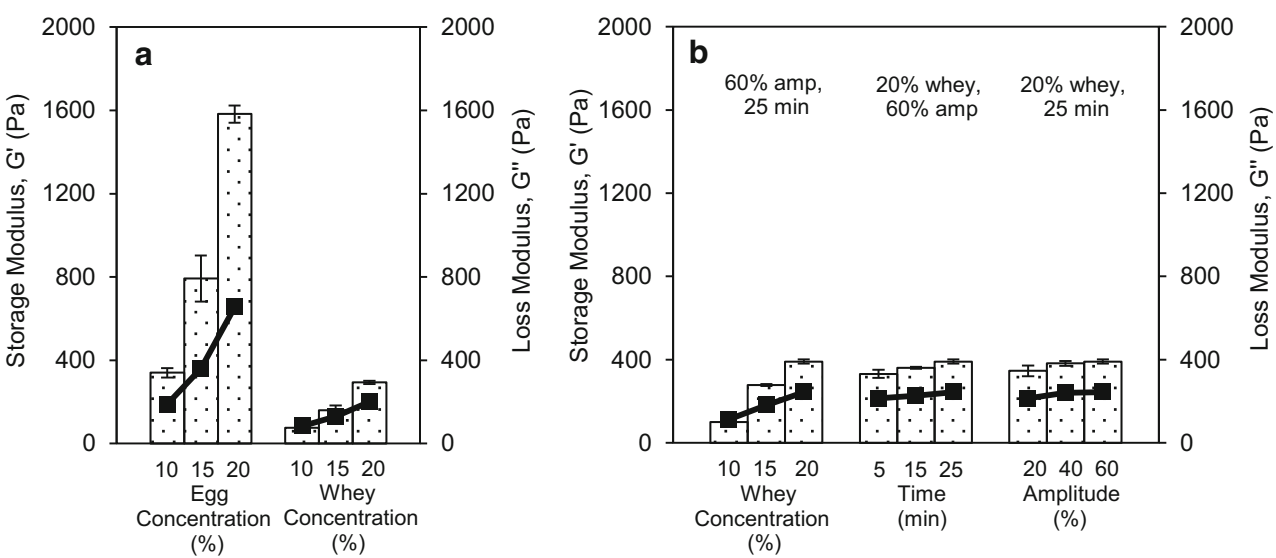

concentration of existing protein components. However, the changes in $\tan \delta$ values, which reflected viscoelasticity, suggest development of different phenomena among the protein components where sonication is linked with the altered physical changes of batter. Batter made from egg also seemed to be more solid and elastic-like with higher $G^{\prime}$ values than $G^{\prime \prime}$ which resulted in lower value of $\tan \delta$. These viscoelastic properties would determine the expansion and stability of air bubbles in batter during baking and indirectly influence the qualities of final cake product in terms of volume and texture. Previous researches had found that whey protein with poor stability will result in cake with lower volume and coarse texture (Arunepanlop et al. 1996; Berry et al. 2009; Yang and Foegeding 2010). Cake batter with higher $G^{\prime}$ was suggested to have better capability of holding bubbles and more stable in the aerated system with a lower batter density (Fig. 1b) (Sahin 2008).

Figure $3 \mathrm{~b}$ shows that viscoelastic properties of whey protein formulated batter increased with ultrasound treatment and was most prominently affected by whey concentration. The highest values of $G^{\prime}$ and $G^{\prime \prime}$ in the presence of ultrasound treatment were obtained at the highest amplitude of $60 \%$ and longest duration of $25 \mathrm{~min}$. Ultrasound treatment on whey protein has increased the viscoelasticity of its formulated batter with decreased $\tan \delta$ (Fig. 4b) reflecting an increase in the predominance of the elastic component (Matos et al. 2014). Sonication has altered the structural property of protein, which induced physical changes on the batter. Banerjee et al. (1996) noted that the edible films of ultrasound treated sodium caseinate and whey protein-based milk had improved mechanical properties, with tensile strength increased up to $224 \%$. It was explained by the reduced particle size of milk components in the film solution which increased the molecular interaction, leading to a more orderly and condensed knit matrix of proteins which increased the cohesion in film, hence contributing to the high film strength (Banerjee et al. 1996; Gontard and Guilbert 1994; Lee and Feng 2011).

\section{Cake Volume and Density}

Figure 5a compares the qualities of baked cake in terms of volume and density, the two important quality measurements for cake by consumers. Cakes with bigger volumes and lower densities were produced with protein concentration increase.
Fig. 4 Loss tangent of a untreated egg and whey protein, and $\mathbf{b}$ ultrasound treated whey protein

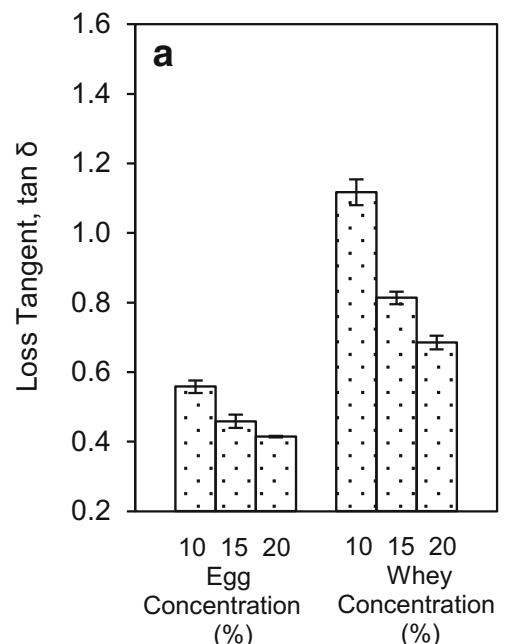

(\%)
(\%)

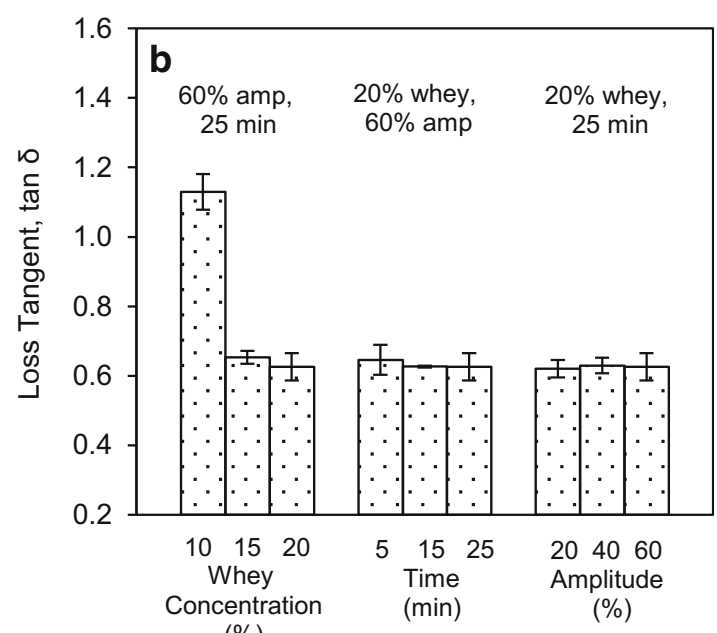

(\%) 
Fig. 5 Volume ( density (- $)$ of cake baked with a untreated egg and whey protein, and $\mathbf{b}$ ultrasound treated whey protein

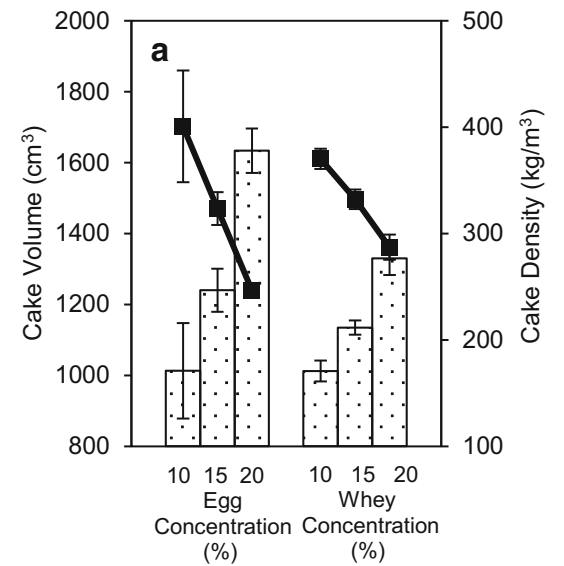

This is explained by the increased network strength of batter with more protein mass, where protein network formed helps to retain incorporated air in cake leavening. A higher volume cake with lower density implies that the cake contained more gas cells. Cake formulated with egg has higher and wider range of volume and density compared to those with whey protein. This was expected and a similar finding was obtained in Abdul Hussain and Al-Oulabi (2009), DeVilbiss et al. (1974), and Mohamed et al. (1995), who reported that whey protein as egg alternative has resulted in lower cake volume. Besides poor batter stability (Pernell et al. 2002), Penfield and Campbell (1990) explained that the lower cake volume was due to the lower batter viscosity (Fig. 1a), which was not sufficiently viscous to minimize the coalescence of gas bubbles and hence caused the loss of leavening gases during baking as large bubbles rise to the surface and escape.

Figure $5 \mathrm{~b}$ shows the qualities of cake baked with ultrasound treated whey protein have improved to meet those baked using egg. Ultrasound treatment had increased cake volume and reduced density significantly, both at $p$ $<0.05$ for amplitude and sonication time. At maximum usage of ultrasound treatment, baked cakes have expanded as much as $18 \%$ in volume and $18 \%$ lighter compared with the untreated whey protein. More interestingly, the volume and density of cake formulated with ultrasound treated whey protein were comparable
Fig. $6 i$ Hardness $(\square)$ and chewiness $(-\mathbf{-}), i$ cohesiveness (EXXI), and resilience ( $\boldsymbol{C})$ of cake baked with a untreated egg and whey protein, and $\mathbf{b}$ ultrasound treated whey protein
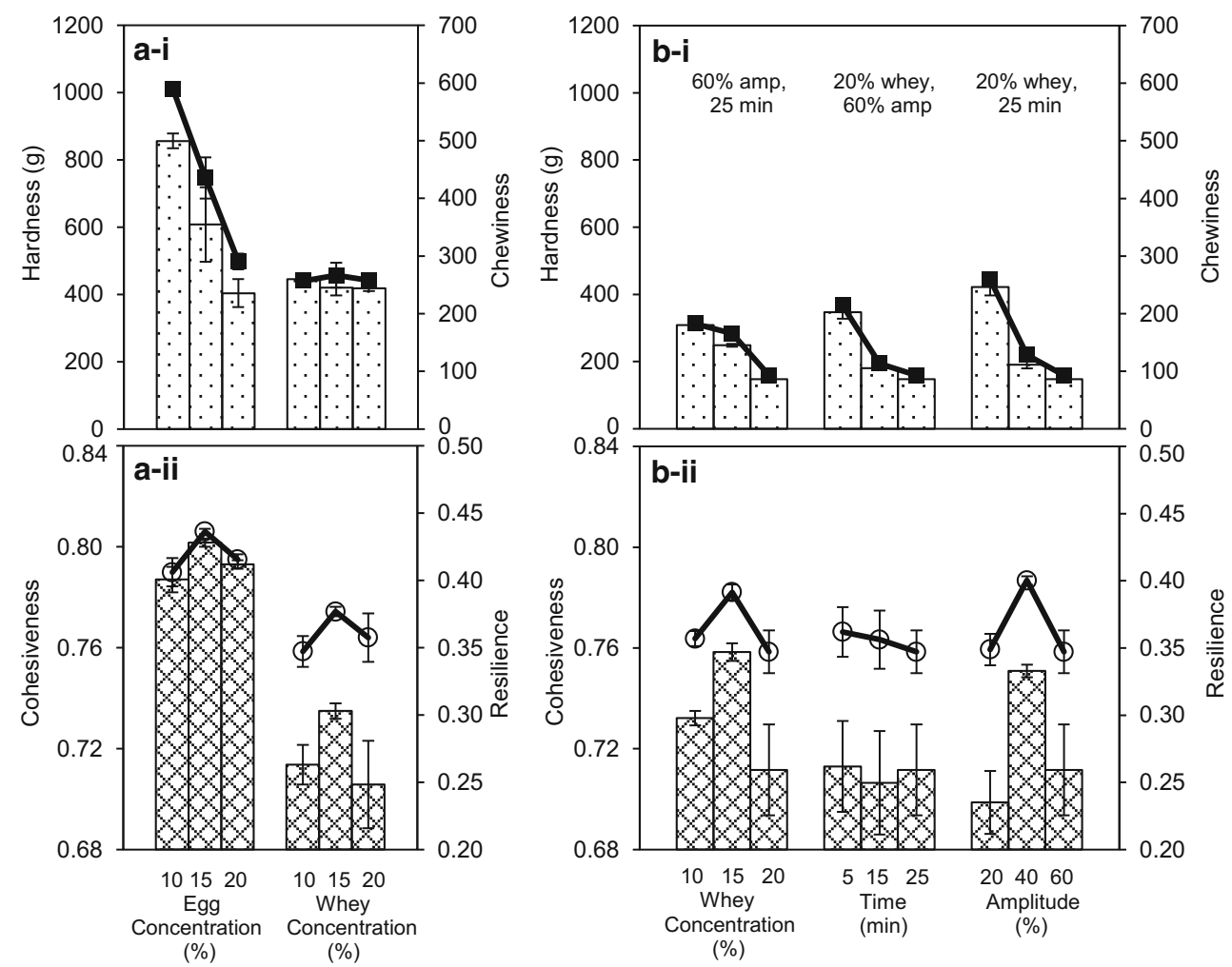
Fig. 7 Internal crumb layer of cakes baked with a untreated whey protein, and ultrasound treated whey protein for $5 \mathrm{~min}$ at b $20 \%$ and c $60 \%$ amplitude, and for $25 \mathrm{~min}$, at $\mathbf{d} 20 \%$ and e $60 \%$ amplitude at $20 \%$ whey protein concentration

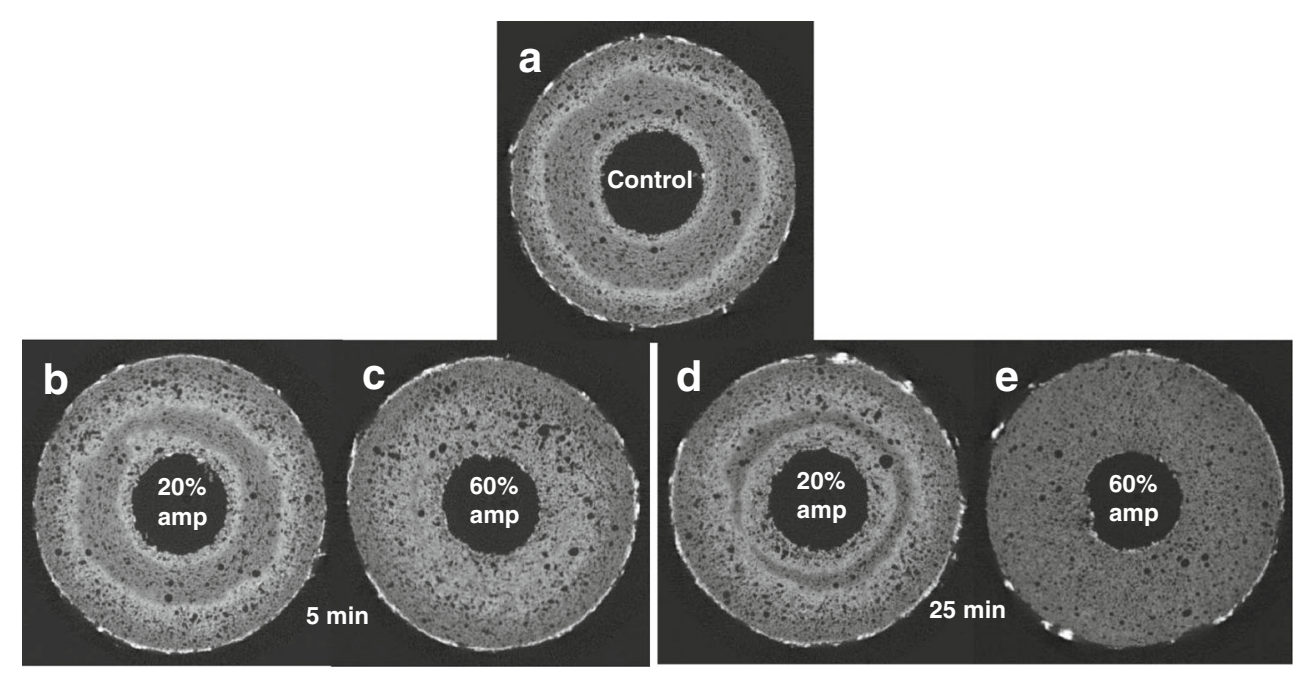

with those made using egg white with a difference of $4 \%$. The ultrasound treatment has induced partial denaturation of protein where it unfolds the polypeptide chains to form strength in film of the continuous phase of foam and batter system to hold entrapped air. This has helped to contribute to the volume.

\section{Textural Properties of Cake}

Cake sensorial properties in terms of hardness and chewiness are commonly used by consumers (Szczesniak 2002; Tan et al. 2010) for evaluating softness and easiness to masticate, while cohesiveness and resilience respectively quantify the internal resistance of the food structure and the ratio of recoverable energy when the first compression is relieved (Lu et al. 2010). Figure 6a-i shows the hardness and chewiness of cake from egg white was significantly affected by its concentration but not for whey protein. This difference is largely due to the textural properties affected by the degree of aeration (Handleman et al. 1961) as cakes from egg white had significantly higher foaming capacity and subsequently produced highly aerated cake. The cohesiveness and resilience of cake from egg white were higher than whey protein as showed in Fig. 6aii. Both cakes from egg white and whey protein have the highest cohesiveness and resilience at $15 \%$ concentration.

Figure 6b-i shows that ultrasound treatment has significantly decreased cake hardness and chewiness at $p<0.001$. Ultrasound treatment in terms of sonication time and amplitude did not have an effect on both cohesiveness and resilience of cake (Fig. 6b-ii). The textural quality improvement on hardness and chewiness was because of the improvement gained during foaming where lower density was attained in the batter system (Fig. 1b). Hardness of cakes baked with untreated whey protein were almost constant (Fig. 6a-i) despite increased cake volume (Fig. 5). The increased number of gas cells due to increased protein concentration had contributed to cake volume with no effect to texture. Large bubbles with variant sizes cause unstable mix and produce coarse and uneven texture (Bennion et al. 1997) in cakes using untreated whey protein.
Fig. 8 Size distributions of gas cells in cakes baked with untreated and ultrasound treated whey protein at $20 \%$ concentration for difference sonication time and amplitude

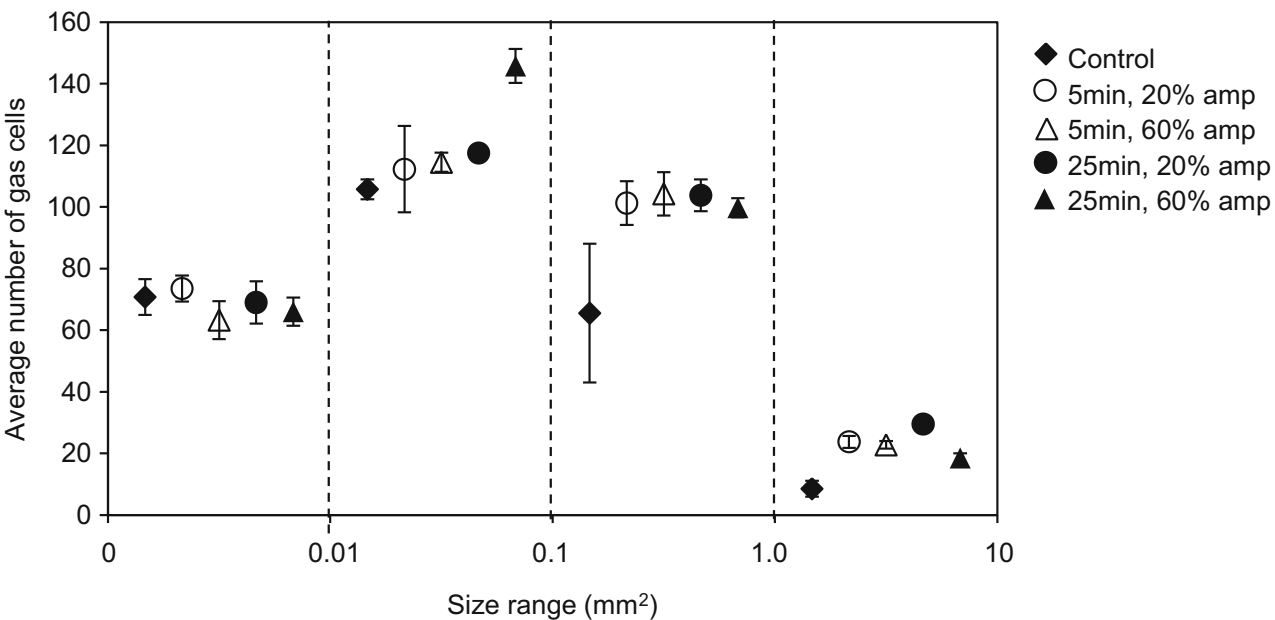


The finer and evenly distributed gas cells in the cake crumb as illustrated in Figs. 7 and 8 for cakes made using ultrasound treated whey protein had contributed to the increased volume and decreased hardness. The improvements in textural properties of cake which underwent ultrasound-assisted mixing was explained by Tan et al.'s (2011) using the ultrasound cavitation theory where it speeded up protein denaturation through bubbles shrinkage effect.

\section{Imaging of Cakes}

Figure 7 shows the crumb images of cakes baked with nontreated whey protein and ultrasound treated whey proteins. The untreated whey protein (Fig. 7a) produced coarse cake texture with less gas cells when compared to cakes treated with ultrasound at maximum amplitude and time (Fig. 7e). This may due to the lower cake batter viscosity of the untreated whey protein (Fig. 1). The ring defects seen with a brighter color observed in the cake with untreated whey (Fig. 7a) was getting smaller when the applied ultrasound increased in amplitude and time intensity. It disappeared when maximum amplitude and sonication time was used (Fig. 7e). The analysis of gas cells distribution (Fig. 8) shows that majority of the gas cells in the cake before and after ultrasound treatment was in the size range of 0.01 to $0.1 \mathrm{~mm}^{2}$. The cake baked with untreated whey protein had the lowest count of bubbles in this range compared to cakes with ultrasound treated whey protein at highest amplitude of $60 \%$ and longest sonication time of 25 min with a $38 \%$ increase. These changes in aerated cake structures due to ultrasound cavitation effect in whey protein suspension is said to have induced a sufficient pressure in sonic waves to cause the air bubbles in protein suspension to fracture and leads to the formation of smaller bubbles (Zheng and Sun 2006). The tiny gas cells that resulted in the cake crumb provided better texture in lower hardness and chewiness (Fig. 6).

\section{Conclusions}

The ultrasound treated whey protein has significantly improved cake batter properties and produced a foam-styled cake with quality comparable to those made using egg proteins. Ultrasound treatment led to better aerated structure in the foaming process measured from its formulated batter properties including density, viscosity, consistency and flow behavior index, and viscoelasticity which produced cakes with higher volume and lower density, hardness, and chewiness. The amount of tiny and evenly distributed gas cells in the cake crumb also increased. The use of ultrasound treated whey protein thus can be a good egg replacer in cake baking without the presence of other functional ingredients.
Acknowledgment This work was supported by the Ministry of Education (MOE), Malaysia, through the Fundamental Research Grant Scheme (FRGS/2/2013/TK05/UPM/02/5).

Open Access This article is distributed under the terms of the Creative Commons Attribution License which permits any use, distribution, and reproduction in any medium, provided the original author(s) and the source are credited.

\section{References}

Abdul Hussain, S. S., \& Al-Oulabi, R. A. (2009). Studying the possibility of preparing an egg-free or egg-less cake. International Journal of Engineering and Technology, 1(4), 324-329.

Abu-Ghoush, M., Herald, T. J., \& Aramouni, F. M. (2010). Comparative study of egg white protein and egg alternatives used in an angel food cake system. Journal of Food Processing and Preservation, 34(s2), 411-425.

Allais, I., Edoura-Gaena, R. B., Gros, J. B., \& Trystram, G. (2006a). Influence of egg type, pressure and mode of incorporation on density and bubble distribution of a lady finger batter. Journal of Food Engineering, 74(2), 198-210.

Allais, I., Edoura-Gaena, R. B., \& Dufour, E. (2006b). Characterisation of lady finger batters and biscuits by fluorescence spectroscopy - relation with density, color and texture. Journal of Food Engineering, 77(4), 896-909.

Anonymous (2013). Angel food cake. http://en.wikipedia.org/wiki/ Angel_food_cake. Accessed 22 Oct 2013.

Arozarena, I., Bertholo, H., Empis, J., Bunger, A., \& Sousa, I. (2001). Study of the total replacement of egg by white lupine protein, emulsifier and xanthan gum in yellow cakes. European Food Research and Technology, 213(4-5), 312-316.

Arunepanlop, B., Morr, C. V., Karleskind, D., \& Laye, I. (1996). Partial replacement of egg white proteins with whey proteins in angel food cakes. Journal of Food Science, 61(5), 1085-1093.

Arzeni, C., Martinez, K., Zema, P., Arias, A., Perez, O. E., \& Pilosof, A. M. R. (2012). Comparative study of high intensity ultrasound effects on food proteins functionality. Journal of Food Engineering, 108(3), 463-472.

Ashwini, A., Jyotsna, R., \& Indrani, D. (2009). Effect of hydrocolloids and emulsifiers on the rheological microstructural and quality characteristics of eggless cake. Food Hydrocolloids, 23(3), 700-707.

Banerjee, R., Chen, H., \& Wu, J. (1996). Milk protein-based edible film mechanical strength changes due to ultrasound process. Journal of Food Science, 61, 824-828.

Bennion, E. B., Bent, A. J., \& Bamford, G. S. T. (1997). The technology of cake making. UK: Blackie Academic \& Professional.

Berry, T. K., Yang, X., \& Foegeding, E. A. (2009). Foams prepared from whey protein isolate and egg white protein: 2 . Changes associated with angel food cake functionality. Journal of Food Science, 74(5), E269-E277.

Boye, J. I., Ma, C.-Y., \& Harwalkar, V. R. (1997). Thermal denaturation and coagulation of proteins. In S. Damodaran \& A. Paraf (Eds.), Food proteins and their applications (pp. 25-26). New York: Dekker.

Chin, N. L., Chan, S. M., Yusof, Y. A., Chuah, T. G., \& Talib, R. A. (2009). Modelling of rheological behaviour of pummelo juice concentrates using master-curve. Journal of Food Engineering, 93(2), 134-140.

Damodaran, S. (1997). Food proteins: an overview. In S. Damodaran \& A. Paraf (Eds.), Food proteins and their applications (pp. 1-24). New York: Dekker.

DeVilbiss, E. D., Holsinger, V. H., Posati, L. P., \& Pallansch, M. I. (1974). Properties of whey protein concentrate foams. Food Technology, 28(3), 40-42. 44, 46, 48.

Gómez, M., Oliete, B., Rosell, C. M., Pando, V., \& Fernández, E. (2008). Studies on cake quality made of wheat-chickpea flour blends. LWT_Food Science and Technology, 41(9), 1701-1709. 
Gómez, M., Moraleja, A., Oliete, B., Ruiz, E., \& Caballero, P. A. (2010). Effect of fibre size on the quality of fibre-enriched layer cakes. LWT_Food Science and Technology, 43(1), 33-38.

Gontard, N., \& Guilbert, S. (1994). Bio-packaging: technology and properties of edible and/or biodegradable material of agricultural origin. In M. Mathlouthi (Ed.), Food packaging and preservation (pp. 159-181). Glasgow: Blackie Academic and Professional.

Gülseren, I., Güzey, D., Bruce, B. D., \& Weiss, J. (2007). Structural and functional changes in ultrasonicated bovine serum albumin solutions. Ultrasonics Sonochemistry, 14(2), 173-183.

Handleman, A. R., Conn, J. F., \& Lyons, J. W. (1961). Bubble mechanics in thick foams and their effects on cake quality. Cereal Chemistry, 38(3), 294.

Harris, S. (2011, November 7). Ultrasound could improve the efficiency of industrial baking. The Engineer.

Ikeda, S., \& Nishinari, K. (2001). "Weak gel”-type rheological properties of aqueous dispersions of nonaggregated Kcarrageenan helices. Journal of Agricultural and Food Chemistry, 49(9), 4436-4441.

Jambrak, A. R., Mason, T. J., Lelas, V., Herceg, Z., \& Herceg, I. L. (2008). Effect of ultrasound treatment on solubility and foaming properties of whey protein suspensions. Journal of Food Engineering, 86(2), 281-287.

Krešić, G., Lelas, V., Jambrak, A. R., Herceg, Z., \& Brnčić, S. R. (2008). Influence of novel food processing technologies on the rheological and thermophysical properties of whey proteins. Journal of Food Engineering, 87(1), 64-73.

Lebesi, D. M., \& Tzia, C. (2012). Use of endoxylanase treated cereal brans for development of dietary fiber enriched cakes. Innovative Food Science and Emerging Technologies, 13, 207-214.

Lee, H., \& Feng, H. (2011). Effect of power ultrasound on food quality. In H. Feng, G. Barbosa-Cánovas, \& J. Weiss (Eds.), Ultrasound technologies for food and bioprocessing (pp. 559-582). New York: Springer.

Lee, C. C., Love, J. A., \& Johnson, L. A. (1993). Sensory and physical properties of cakes with bovine plasma products substituted for egg. Cereal Chemistry, 70(1), 18-21.

Lu, T. M., Lee, C. C., Mau, J. L., \& Lin, S. D. (2010). Quality and antioxidant property of green tea sponge cake. Food Chemistry, 119(3), 1090-1095.

Matos, M. E., Sanz, T., \& Rosell, C. M. (2014). Establishing the function of proteins on the rheological and quality properties of rice based gluten free muffins. Food Hydrocolloids, 35, 150-158.

McWilliams, M. (2008). Foods: experimental perspectives (6th ed.). New Jersey: Pearson Prentice Hall.

Mleko, S., Kristinsson, H. G., Liang, Y., \& Gustaw, W. (2007). Rheological properties of foams generated from egg albumin after $\mathrm{pH}$ treatment. LWT-Food Science and Technology, 40(5), 908-914.

Mohamed, S., Lajis, S. M. M., \& Hamid, N. A. (1995). Effects of protein from different sources on the characteristics of sponge cakes, rice cakes (apam), doughnuts and frying batters. Journal of the Science of Food and Agriculture, 68(3), 271-277.

Morr, C. V., Hoffmann, W., \& Buchheim, W. (2003). Use of applied air pressure to improve the baking properties of whey protein isolated in angel food cakes. LWT-Food Science and Technology, 36(1), 83-90.

Myhara, R. M., \& Kruger, G. (1998). The performance of decolorized bovine plasma protein as a replacement for egg white in high ratio white cakes. Food Quality and Preference, 9(3), 135-138.
Nakai, S., \& Li-Chan, E. (1985). Structure modification and functionality of whey proteins: quantitative structure-activity relationship approach. Journal of Dairy Science, 68(10), 2763-2772.

Penfield, M. P., \& Campbell, A. M. (1990). Experimental food science (3rd ed.). San Diego: Academic.

Pernell, C. W., Luck, P. J., AllenFoegeding, E., \& Daubert, C. R. (2002). Heat-induced changes in angel food cakes containing egg-white protein or whey protein isolate. Journal of Food Science, 67(8), 2945-2951.

Raeker, M. O., \& Johnson, L. A. (1995). Cake-baking (high-ratio white layer) properties of egg white, bovine blood plasma, and their protein fractions. Cereal Chemistry, 72(3), 299-303.

Recio, I., Ramos, M., \& Pilosof, A. M. R. (2008). Engineered food/ protein structure and bioactive proteins and peptides from whey. In G. F. Gutierrez-Lopez, G. V. Barbosa-Canovas, J. Welti-Chanes, \& E. Parada-Arias (Eds.), Food engineering integrated approaches (pp. 399-414). New York: Springer.

Sahin, S. (2008). Cake batter rheology. In S. G. Sumnu \& S. Sahin (Eds.), Food engineering aspects of baking sweet goods (pp. 99-119). New York: Taylor \& Francis.

Sahin, S., \& Sumnu, S. G. (2006). Physical properties of foods. New York: Springer.

Sakiyan, O., Sumnu, G., Sahin, S., \& Bayram, G. (2004). Influence of fat content and emulsifier type on the rheological properties of cake batter. European Food Research and Technology, 219(6), 635-638.

Salvador, A., Sanz, T., \& Fiszman, S. M. (2003). Rheological properties of batters for coating products - effect of addition of corn flour and salt. Food Science and Technology International, 9(1), 23-25.

Szczesniak, A. S. (2002). Texture is a sensory property. Food Quality and Preference, 13(4), 215-225.

Tan, M. C., Chin, N. L., \& Yusof, Y. A. (2010). A Box-Behnken design for determining the optimum experimental condition of cake batter mixing. Food and Bioprocess Technology, 5(3), 972-982.

Tan, M. C., Chin, N. L., \& Yusof, Y. A. (2011). Power ultrasound aided batter mixing for sponge cake batter. Journal of Food Engineering, 104(3), 430-437.

Tan, M. C., Chin, N. L., Yusof, Y. A., Taip, F. S., \& Abdullah, J. (2014). Characterization of improved foam aeration and rheological properties of ultrasonically treated whey protein suspension. International Dairy Journal. doi:10.1016/j.idairyj.2014.09.013.

Turabi, E., Sumnu, G., \& Sahin, S. (2008). Rheological properties and quality of rice formulated with different gums and an emulsifier blend. Food Hydrocolloids, 22(2), 305-312.

Villamiel, M., \& de Jong, P. (2000). Influence of high-intensity ultrasound and heat treatment in continuous flow on fat, proteins, and native enzymes of milk. Journal of Agricultural and Food Chemistry, 48(2), 472-478.

Yamazaki, W. T., \& Lord, D. D. (1971). Soft wheat flour products. In Y. Pomeranz (Ed.), Wheat chemistry technology (pp. 743-776). USA: American Association of Cereal Chemists.

Yang, X., \& Foegeding, E. A. (2010). Effects of sucrose on egg white protein and whey protein isolate foams: factors determining properties of wet and dry foams (cakes). Food Hydrocolloids, 24(2), 227-238.

Zheng, L., \& Sun, D. W. (2006). Innovative applications of power ultrasound during food freezing processes - a review. Trends in Food Science \& Technology, 17(1), 16-23.

Çelik, İ., Yilmaz, Y., Ișik, F., \& Üstün, Ö. (2007). Effect of soapwort extract on physical and sensory properties of sponge cakes and rheological properties of sponge cake batters. Food Chemistry, 101(3), 907-911. 